\title{
RECONCILING SHAREHOLDERS' RIGHTS AND CORPORATE RESPONSIBILITY: NEW GUIDELINES FOR MANAGEMENT
}

\author{
LARRY D. SODERQUIST* and ROBERT P. VECCHIO**
}

Several decades ago Professors Berle and Dodd began an interesting debate. ${ }^{1}$ Among other things, it concerned the nature of the shareholders' relationship to large, publicly held corporations in which they had invested and the responsibility of these corporations to groups such as customers, employees, and persons residing in the communities in which they operate. The debate has continued, drawing in other participants and generating a diverse group of theories. After examining current legal formulations of the shareholders' relationship to large, publicly held corporations, ${ }^{2}$ and current concepts of corporate responsibility, this Article will discuss some of these theories in light of empirical research done by the authors with respect to shareholders' expectations. The Article will then present some of the authors' theories, which are based in part upon that research.

\section{Shareholding as Ownership: The Traditional CONCEPTUALIZATION}

\section{A. The Model's Basic Framework.}

In the traditional model of the corporation, shareholders convert their individual property into an equity share in the enterprise's collective capital. ${ }^{3}$ The corporation becomes an entity distinct from the natu-

* Associate Professor of Law, University of Notre Dame. B.S. 1966, Eastern Michigan University; J.D. 1969, Harvard University.

** Assistant Professor of Management, University of Notre Dame. B.S. 1972, De Paul University; Ph.D. (Industrial Psychology) 1976, University of Illinois.

The authors wish to acknowledge the research assistance of Mary E. Shaffner, J.D. 1978, University of Notre Dame.

THE FOLLOWING CITATION WILL BE USED IN THIS ARTICLE:

Dodd, For Whom are Corporate Managers Trustees?, 45 HARV. L. REv. 1145 (1932) [hereinafter cited as Dodd, Trustees].

1. See notes 77-78 infra and text accompanying notes 77-82 infra.

2. Since this Article will focus on the large, publicly held corporation, the authors will in most cases forego the modifiers and speak simply of "corporations."

3. This contribution to capital by individual shareholders is both the event that entitles the shareholder to benefit from the advantages of corporate organization, such as that of limited liability, and that marks the creation of the rights shareholders receive in return for their capital, 
ral persons who comprise its membership, ${ }^{4}$ and is regarded as a private association organized for the mutual gain of its individual members. ${ }^{5}$ The entity, rather than the shareholders, owns the corporate property, and this structure preserves the continuity of the venture regardless of the ownership changes of individual shareholders. ${ }^{6}$ Nevertheless, the corporation is still discernible as a collection of individuals who have merely chosen to clothe their ownership of property in the legal guise of the corporate form. ${ }^{7}$ From the traditional legal standpoint, therefore, the shareholder owns the corporation "in the proportion that his stock bears to the entire stock."

such as the right to profits in the form of dividends and the right to a proportionate share upon the dissolution of the corporation. In the traditional ownership model it represents the actual purchase of part ownership in the corporation. See United Grocers, Ltd. v. United States, 186 F. Supp. 724 (N.D.Cal. 1960), aff'd, 308 F.2d 634 (9th Cir. 1962) (contribution to capital and the receipt of certain rights vis a vis the corporation by the shareholder in exchange); State ex rel Waldman v. Miller-Wohl Co., 28 A.2d 148 (Del. Super. Ct. 1942) (corporation in fact an aggregate of individuals who share in the corporate equity); Brooks v. Eschwege, 108 Ohio App. 567, 162 N.E.2d 897 (1957) (stock in a corporation represents actual purchase of part ownership). See generally 18 C.J.S. Corporations $\$ 6$ (1939).

4. McCarroll v. Ozarks Rural Elec. Co-op. Corp., 201 Ark. 329, 146 S.W.2d 693 (1941); Bird v. Wilmington Soc'y of the Fine Arts, 28 Del. Ch. 449, 43 A.2d 476 (1945); Whitfield v. Kern, 122 N.J. Eq. 332, 346, 192 A. 48, 56 (1937). See also H. HENN, LAw of CoRPORATIONs 108-09 (2d ed. 1970) for a concise discussion of the various entity theories.

5. Altoona Warehouse Co. v. Bynum, 242 Ala. 540, 7 So.2d 497 (1942); Dodd, Trustees 1146.

6. Chief Justice Marshall, in one of the earliest analyses in American law of the nature of a corporation, emphasized that perpetuity of ownership is both the salient characteristic and raison d'etre of corporate organization. Trustees of Dartmouth College v. Woodward, 17 U.S. (4 Wheat.) 518,636 (1819).

7. A business organization that utilizes the corporate form allows individual investors to act as one for the purpose of transacting business. Emanuel v. Jaeger, 117 F.2d 483 (2d Cir. 1941); State ex rel. Waldman v. Miller-Wahl Co., 28 A.2d 148 (Del. Super. Ct. 1942). Normally, the law will not attribute the acts of the shareholders to the corporation and vice-versa. In compelling circumstances, however, corporations will be revealed as a mere aggregate of investors. By doing away with the corporate veil in such cases, equity reminds shareholders that the corporate fiction is actually a revocable privilege granted by the state. "Equity . . . disregards the corporate body as a legal entity distinct from its members, and recognizes that while stockholders have no legal title to the corporate assets, they are nevertheless the equitable owners thereof." Waller v. Waller, 187 Md. 185, 191, 49 A.2d 449, 453 (1946). See also Whipple v. Industrial Comm'n, 59 Ariz. 1, 121 P.2d 876 (1942).

8. Elko Lamoille Power Co. v. Commissioner, 50 F.2d 595, 596 (9th Cir. 1931). See also Schoenbaum v. Firstbrook, 405 F.2d 200, 215 (2d Cir. 1968) (Hays, J., concurring in part and dissenting in part), rev'd on rehearing, 405 F.2d 215 (2d Cir. 1968), cert. denied, 395 U.S. 906 (1960). It was Judge Hays's contention that for the purpose of determining the existence of deception for a Rule 10b-5 violation, a showing that the directors, while fully aware of all material information, withheld this information from "the real owners of the property with which the directors were dealing," that is, the shareholders, was sufficient to prevent a summary judgment against plaintiff shareholders. On rehearing, Judge Hays wrote the court's opinion. 
The shareholder's ownership quite patently does not involve any direct physical possession of, or right to decide the use of, the corporation's assets. ${ }^{9}$ He instead possesses a collection of incorporeal proprietary rights relating to the corporation. ${ }^{10}$ Shareholders are, for example, entitled to profits in the form of dividends and to information as to how the business is being conducted. ${ }^{11}$ They also have the right to insist that management govern the corporation in the interest of all the shareholders, and particularly that management not waste assets nor apply them for unauthorized purposes. ${ }^{12}$

Despite these indicia of ownership, shareholders (by virtue of the merger of their individual investment into the collective property of the corporation) have parted with direct control over the uses of their individual property. ${ }^{13}$ In the traditional model, actual control is wielded by a board of directors that formulates long-term policy and exercises general supervision, and by executives who implement board policy and make day to day decisions in operating the enterprise. ${ }^{14}$

9. "In a sense, the stockholders of a corporation own its property, but they are not managers of its business or in the immediate control of its affairs." Pullman Palace Car Co. v. Missouri Pac. Ry., 115 U.S. 587, 597 (1885).

10. Jellenik v. Huron Copper Mining Co., 177 U.S. 1, 12-13 (1900); see Commissioner v. Scateng, 85 F.2d 729 (9th Cir. 1936); Department of Treasury v. Crowder, 214 Ind. 252, 15 N.E.2d 89 (1939); Jay Ronald Co. v. Marshall Mortgage Corp., 265 App. Div. 622, 40 N.Y.S.2d 391 (1943), rev'd, 291 N.Y. 227, 52 N.E.2d 108 (1943).

11. Although, generally speaking, shareholders have the right to information and to inspect corporate books, they do not have unlimited access to the books. Rather, they need a proper purpose in requesting access, presumably to avoid undue shareholder meddling in management's legitimate efforts to conduct corporate business. Normally, however, the burden is upon the corporation to show an improper purpose. State ex rel. Foster v. Standard Oil Co., 18 A.2d 235 (Del. Super. Ct. 1941) (holding that the shareholder's right to inspect the books is absolute, unless an improper motive is established by the corporation); accord, Hughey v. DuBois Press, Inc., 36 N.Y.S.2d 220 (Sup. Ct. 1942).

For cases discussing the general proposition that shareholders have a right to receive information about the corporation, see In re Bush Terminal Co., 78 F.2d 662, 663 (2d Cir. 1935); DuPont v. DuPont, 42 Del. Ch. 246, 208 A.2d 509 (Sup. Ct. 1965); Bruun v. Cook, 280 Mich. 484, 273 N.W. 774 (1937).

12. Schwarz v. Artcraft Silk Hosiery Mills, Inc., 110 F.2d 465 (2d Cir. 1940) (corporate officers are liable to shareholders under New York law for mismanagement); Baker v. Cohn, 42 N.Y.S.2d 159 (Sup. Ct. 1942), modified, 266 App. Div. 715, 40 N.Y.S.2d 623 (1943) (duty not to waste assets is part of honest business management); Stokes v. Continental Trust Co., 186 N.Y. 285, 78 N.E. 1090 (1906).

13. Pullman Palace Car Co. v. Missouri Pac. Ry., 115 U.S. 587, 597 (1885). See Hetherington, Fact and Legal Theory: Shareholders, Managers and Corporate Social Responsibility, 21 STAN. L. Rev. 248, 250-55 (1969); Berle, Property, Production and Revolution, 65 ColuM. L. REv. 1, 8 (1965).

14. State corporation statutes and the Model Business Corporation Act vest the right to manage the business and affairs of the corporation in the board of directors, although the Model Act, the Delaware statute and several other state statutes allow shareholders to limit this power in the articles of incorporation. See, e.g., ABA-ALI MODEL Bus. CoRP. ACT $\$ 35$ (1974); DEL. CODE 
A division between ownership and contro ${ }^{15}$ is thus inherent in the traditional corporate model as one of the costs of choosing the corporate form of doing business. Yet in this model, the shareholder's surrender of his proprietary prerogatives is not absolute, for he retains certain basic protections. Perhaps the most fundamental is the right to elect directors. ${ }^{16}$ It is assumed by the traditional model that shareholders through the annual meeting have the power to require management to account for their actions, and that they can show approval of management decisions by re-electing the directors. ${ }^{17}$ Shareholders are also assumed to have the power to replace the board with a new slate of individuals who, hopefully sobered by their predecessors' fate, will be better attuned to the shareholders' wishes. The right to elect directors, in the traditional legal model, represents the shareholder's private right to participate in the corporation's management and permits ultimate control over the enterprise. ${ }^{18}$

A second complementary protection flows by necessity from the practical problems of restraining managerial misuse of what is, in the traditional model, assumed to be the shareholders' money. ${ }^{19}$ To provide this protection, the law treats directors not merely as the agents

ANN. tit. 8, § 141 (Cum. Supp. 1977); N.J. STAT. ANN. § 14A:6-1 (West Cum. Supp. 1977-1978); N.Y. Bus. CoRp. LAw $\$ 701$ (McKinney Cum. Supp. 1977-1978). The case law elaborating on the managerial powers of the board of directors and top executives is voluminous. See, e.g., Hausman v. Buckley, 299 F.2d 696 (2d Cir. 1962); Olson Bros. v. Englehart, 42 Del. Ch. 348, 211 A.2d 610 (1965); Abercrombie v. Davies, 35 Del. Ch. 599, 123 A.2d 893 (1956); Shonnard v. Elevator Supplies Co., 111 N.J. Eq. 94, 161 A. 684 (Ch. 1932); cf. In re Kaufman Mutual Fund Action, 479 F.2d 257 (1st Cir. 1973) (discussing the allegations that a shareholder must make respecting the conduct of corporate directors in order to bring a derivative action).

Of course, the traditional model does not reflect reality in these respects. Control is not typically wielded by the board of directors, and neither does the board usually formulate long-term policy or exercise supervision, at least in the usual sense of that word. See, e.g., M. EISENBERG, The Structure of the Corporation: A Legal Analysis 139-48 (1976); M. Mace, DireCTORS: MYTH AND REALITY (1971).

15. The concept of the separation of ownership from control was articulated by Berle and Means in describing what they considered to be the foremost characteristic of the modern corporation: the removal from shareholders and the vesting in management of the power to control the corporation's activities. A. Berle \& G. Means, The Modern Corporation and Private PropERTY 5 (rev. ed. 1967).

16. Stokes v. Continental Trust Co., 186 N.Y. 285, 78 N.E. 1090 (1906). See also Bijur v. Standard Distillation \& Distrib. Co., 74 N.J. Eq. 546, 70 A. 934 (Ch. 1908).

17. State incorporation statutes have specified that the directors are to be elected by shareholders and that no director may take office until he has been elected and qualified. See, e.g., DeL. Code ANN. tit.-8, §§ 141, 211 (1975 \& Cum. Supp. 1977); N.J. STAT. ANN. §§ 14A:5-2, 14A:6-3, 14A:6-5 (West 1969 \& Cum. Supp. 1977); N.Y. Bus. CoRP. LAW $\$ 703$ (McKinney 1963).

18. Lee v. Riefler \& Sons, 43 F.2d 364, 365 (M.D. Pa. 1930); Bijur v. Standard Distillation \& Distrib. Co., 74 N.J. Eq. 546, 70 A. 934 (Ch. 1908).

19. For an early complaint about management, see A. SMITH, WEALTH of NATIONS, bk. V, ch. I, pt. III, art. I (Campbell, Skinner \& Todd eds. 1976). 
and instrumentalities through which the enterprise's business is carried on, but as fiduciaries: "Directors of a corporation are trustees for the stockholders, and their acts are governed by the rules applicable to such a relation, which exact of them the utmost good faith and fair dealing . . . ." ${ }^{20}$ Directors, "to whom law intrusts the power of management and control," 21 are governed by stringent rules of fiduciary conduct which, as one court insisted, "rise far above the ordinary morals of the marketplace." 22 The directors owe an allegiance to the corporation "that is influenced in action by no consideration other than [its] welfare."23 Some courts have admittedly distinguished the director's fiduciary duty owed to the corporation on the one hand from possible fiduciary duties owed personally to shareholders on the other. ${ }^{24}$ In this regard, however, it seems clear that management's fiduciary duty to the corporation has in the traditional corporate model been thought of as existing for the benefit of shareholders. ${ }^{25}$

Finally, it is clear that the traditional concepts of ownership, albeit adapted somewhat to fit the corporate entity, form the major analytical tool used by courts in settling shareholder/corporate disputes. In these situations, protection of the shareholders' ownership interest is para-

20. Lofland v. Cahall, 13 Del. Ch. 384, 389, 118 A. 1, 3 (1922). For other cases discussing directors' and other managers' fiduciary duties, see generally Guft v. Loft, Inc., 23 Del. Ch. 255,5 A.2d 503 (1939); Bowen v. Imperial Theatres, Inc., 13 Del. Ch. 120, 115 A. 918 (1922); Eliasberg v. Standard Oil Co., 23 N.J. Super. 431, 92 A.2d 862 (Super. Ct. 1952); Stephany v. Marsden, 75 N.J. Eq. 90, 71 A. 598 (Ch. 1908).

21. Stokes v. Continental Trust Co., 186 N.Y. 285, 296, 78 N.E. 1090, 1093 (1906).

22. United States v. Gates, 376 F.2d 65, 77 (10th Cir. 1967) (quoting Wooten v. Wooten, 151 F.2d 147, 149 (10th Cir. 1945)). The Sixth Circuit in Ashman v. Miller, 101 F.2d 85 (6th Cir. 1939), rather pointedly stated the rationale underlying the stringent standards of fiduciary duty that management must observe: "[S]o many artificial legal devices have been set up which serve to isolate the stockholder from control over his investment that directors and other officers of a corporation should be held to a strict accountability for their acts in its management." Id. at 91.

23. Turner v. American Metal Co., 36 N.Y.S.2d 356, 369 (1942). See also Elliott v. Baker, 194 Mass. 518, 523, 80 N.E. 450, 452 (1907). It is also worth noting that a number of courts, presumably due to their general protectiveness over shareholders' perquisites of ownership, have extended these fiduciary standards to all persons, including other shareholders, in a position to exercise control over the corporation. See, e.g., Harriman v. E.I. Du Pont De Nemours \& Co., 372 F. Supp. 101, 106 (D. Del. 1974): "[O]ne who exercises control over a corporation which in turn exercises control over a Delaware corporation may have a fiduciary duty to the latter corporation."

24. For an exhaustive study of directors' fiduciary duties, especially in relation to duties owed to the corporation as opposed to those owed to shareholders, see Bayne, The Fiduciary Duty of Management-The Concept in the Courts, 35 U. DET. L.J. 561 (1958).

25. Chenery Corp. v. SEC, 128 F.2d 303, 308-09 (D.C. Cir. 1942), modified in 318 U.S. 80 (1943). See generally In re Westec Corp., 434 F.2d 195 (5th Cir. 1970); Wilshire Oil Co. v. Riffe, 381 F.2d 646 (10th Cir.), cert. denied, 389 U.S. 822 (1967); Lawrence v. I.N. Parlier Estate Co., 15 Cal. 2d 220, 100 P.2d 765 (1940); Angelus Sec. Corp. v. Ball, 20 Cal. App. 2d 436 (1937); Bingham v. Ditler, 309 Ill. App. 581, 33 N.E.2d 939 (1941). 
mount, for the ownership model of the corporation has become axiomatic in American law. ${ }^{26}$ Cases employing this analytical tool have balanced the rights of shareholder-owners against management's need for adequate compensation, ${ }^{27}$ distribution problems upon dissolution ${ }^{28}$ and recapitalization measures affecting shareholder voting power ${ }^{29}$ In these cases, the judiciary has frequently and vigorously defended the concept of shareholder ownership. Consider, for example, the New York Court of Appeals' affirmation of this principle in Stokes v. Continental Trust Co.:

What is the nature of the right acquired by a stockholder through the ownership of shares of stock? What rights can he assert . . .? While he does not own and cannot dispose of any specific property of the corporation, yet he and his associates own the corporation itself, its charter, franchises, and all rights conferred thereby . . . . ${ }^{30}$

The Stokes case, and those like it, applied the protections derived from the concept of ownership to reverse management decisions that diluted shareholder voting power. ${ }^{31}$ More pertinently, for our purposes, the conceptualization of shareholders as owners has supplied the philosophical underpinnings for judicial elaborations of the proper goals of the corporate enterprise, especially in cases where management has responded to the interests of groups other than shareholders. In modern terms, these situations involve questions of corporate responsibility that conflict with the shareholder's proprietary rights.

26. Miles v. Safe Deposit \& Trust Co., 259 U.S. 247, 252 (1922). The Court's opinion used the term "axiomatic," in the context of a shareholder's right to participate in new stock issues, in preference to strangers, to describe the principle holding that this right springs from the prerogatives given to the shareholders as proportionate owners of the old capital. The Court's reference reflects the pervasiveness of the ownership model in American corporate jurisprudence. For other examples of the use of this model, see note 8 supra and accompanying text.

27. See generally Rogers v. Hill, 289 U.S. 582 (1933); Richardson v. Blue Grass Mining Co., 29 F. Supp. 658 (E.D. Ky. 1939), affd per curiam, 127 F.2d 291 (6th Cir.), cert. denied, 317 U.S. 639 (1942). But see Gallin v. National City Bank, 152 Misc. 679, 273 N.Y.S. 87 (Sup. Ct. 1934).

28. Neill v. Phinney, 245 F.2d 645, 651 (5th Cir. 1957); Chevron Oil Co. v. Clark, 291 F. Supp. 552 (S.D. Miss. 1968), aff'd in part, rev'd in part, 432 F.2d 280 (5th Cir. 1970); Kirby Royalties, Inc. v. Texaco, Inc., 461 P.2d 282, 283-84 (Wyo. 1969).

29. Borg v. International Silver Co., 11 F.2d 147 (2d Cir. 1925); Horwitz v. Balaban, 112 F. Supp. 99 (S.D.N.Y. 1949); Bates v. United Shoe Mach. Co., 206 F. 716 (E.D.N.Y. 1913); Snelling v. Richard, 166 F. 635 (S.D.N.Y. 1909).

30. 186 N.Y. 285, 295, 78 N.E. 1090, 1093 (1906).

31. For cases using a rationale similar to that of Stokes in discussing shareholder voting rights, see Borg v. International Silver Co., 11 F.2d 147 (2d Cir. 1925); Horwitz v. Balaban, 112 F. Supp. 99 (S.D.N.Y. 1949); Dunlay v. Avenue M Garage \& Repair Co., 253 N.Y. 274, 170 N.E. 917 (1930). As the Stokes court ruefully admitted, the purpose of this protectiveness is to safeguard the shareholders' power to select directors, which is "about all the power" they have. Stokes v. Continental Trust Co., 186 N.Y. 285, 296, 78 N.E. 1090, 1093 (1906). 
One of the earliest case precedents, Dodge v. Ford Motor Co., ${ }^{32}$ dealt strongly with management attempts to consider in decision making a constituency broader than shareholders. In Dodge, Henry Ford's expansionist corporate notions and zeal for selling his cars to the public at a price they could afford, but at the expense of maximum profit levels, clashed with the expectations of Ford's shareholders. ${ }^{33}$ The Michigan Supreme Court sided with the irate shareholders. It bluntly asserted:

A business corporation is organized and carried on primarily for the profit of the stockholders. The powers of the directors are to be employed for that end. The discretion of directors is to be exercised in the choice of means to attain that end, and does not extend to a change in the end itself, to the reduction of profits, or to the nondistribution of profits among stockholders in order to devote them to other purposes. ${ }^{34}$

Management may conceive that it owes a duty to the public, but, according to the Dodge decision, it must not confuse its enlightened ideas with its established duties to shareholders-the only duties this court was prepared to recognize. ${ }^{35}$ In terms of its factual situation, Dodge stands virtually by itself. Most other cases dealing with questions of corporate actions that conflict with shareholder proprietary rights have involved corporate charitable contributions or employee benefit programs.

\section{B. Charitable Contributions and Employee Benefits: \\ The Corporate Benefit Rule.}

Shareholders have in some well-known cases asserted their prerogatives as owners, charging that a particular charitable contribution or course of action was ultra vires, a waste of assets and/or a breach of the corporate managers' fiduciary duty. Courts initially agreed with them,

32. 204 Mich. 459, 170 N.W. 668 (1919).

33. As the Michigan Supreme Court emphasized in its opinion, Ford Motor Company had just concluded the most profitable year in its history. Henry Ford, however, persuaded the board not to vote any special dividends despite the enormous surplus, but rather to use the cash to expand the company's capacities by constructing its own smelting plant to produce steel for its cars. He further determined that, because the company was making such a great profit, he would reduce the selling price of Ford cars in order to share the company's profits with the rest of the public. The plan's "apparent immediate effect," the Michigan court noted, "[would] be to diminish the value of shares and the returns to shareholders." Id. at 504, 170 N.W. at 683.

34. Id. at $507,170 \mathrm{~N}$.W. at 684 . Although the court criticized Henry Ford's actions as unnecessary and improper philanthropy, it hesitated to halt Ford's plans for expansion. As Dodd noted, the court may have limited its decree from its conscious or unconscious reluctance to interfere with the growth of a socially important enterprise. Dodd, Trustees 1157-58 n.31.

35. 204 Mich. at 459,170 N.W. at 668. 
discouraging managers, to borrow Lord Justice Bowen's metaphor from Hutton v. West Cork Ry. ${ }^{36}$ with cakes-and-ale notions. Out of the Hutton case, a strict common law rule developed prohibiting corporate charitable activities unless a direct benefit accrued to the corporation. ${ }^{37}$

Like most strict rules, the direct benefit rule proved difficult to live with, both for courts and for management. Enlightened recognition of corporate self-interest, fueled by pressures from the idea of good public and employee relations, began to take root in judicial philosophies. ${ }^{38}$ Gradually, the strict "direct benefit" rule was liberalized in order to allow charitable and other activities if they served corporate ends in a substantial sense. ${ }^{39}$ In an early and leading case on this question, Steinway v. Steinway, ${ }^{40}$ the New York Supreme Court upheld company plans to build an employee town complete with a school, a church and a library, on the basis that these actions were taken for the benefit of the corporation. ${ }^{41}$ By no means, however, did the Steinway court intend to broaden the direct benefit rule so as to allow corporate actions which benefited persons other than shareholders, as the Michigan Supreme Court reminded the defendants in Dodge. ${ }^{42}$ In the latter case, the court recognized a difference in degree and kind between a merely "incidental humanitarian expenditure of corporate funds," 43 as found in Steinway, and "a general purpose and plan to benefit mankind at the

36. [1883] $23 \mathrm{Ch}$. 654. Almost one hundred years ago, Lord Justice Bowen articulated the early common law standard against which corporate charitable activities should be measured: "The law does not say that there are to be no cakes and ale, but there are to be no cakes and ale except such as are required for the benefit of the company." Id. at 673 .

37. West Cork Ry. has, in fact, remained the leading case articulating the narrow direct benefit test limiting corporate charitable and other philanthropic activities. The English Chancery Court, in the context of compensation of directors, ruled that because any money spent belongs to the corporation, the expenditure must procure some benefit required for the well-being of the company. See id. at $671,673$.

38. In People ex rel. Metropolitan Life Ins. Co. v. Hotchkiss, 136 App. Div. 150, 120 N.Y.S. 649 (1909), the New York appellate court discussed both the philosophy of enlightened corporate self-interest and good employee relations. The State of New York charged in this case that the defendant corporation had violated state insurance laws in connection with its purchase of real estate to build an employee tuberculosis hospital. Although corporations still use the enlightened self-interest doctrine to justify social efforts, their justifications have become increasingly sophisticated. See Blumberg, Corporate Responsibility and the Social Crisis, 50 B.U.L. REv. 157 (1970).

39. Greene County Nat'l Farm Ass'n v. Federal Land Bank, 57 F. Supp. 783 (W.D. Ky. 1944), aff'd, 152 F.2d 215 (6th Cir. 1945), cert. denied, 328 U.S. 834 (1946); Evans v. Brunner, Mond \& Co., [1921] 1 Ch. 359.

40. 17 Misc. 43,40 N.Y.S. 718 (1896).

41. Id. at $47-49,40$ N.Y.S. at $720-22$.

42. 204 Mich. at 506-07, 170 N.W. at 684 . The Dodge defendants argued that Henry Ford's plan to reduce the selling price of Ford cars constituted a benefit to the corporation similar to those permitted by the Steinway doctrine.

43. Id. at 506,170 N.W. at 684 . 
expense of others." 44

Over the years numerous courts found benefits to the corporation and, ultimately, to shareholders, via tenuous connections between corporate advantage and the particular activity involved. For example, they permitted corporations to build employee tuberculosis hospitals, ${ }^{45}$ to donate to business schools, ${ }^{46}$ to participate in a business organization dedicated to uncovering deceptive business practices ${ }^{47}$ and to cancel farm debts in an area dependent on a healthy farm economy. ${ }^{48}$

\section{The Old vs. the New: A.P. Smith and Its Progeny.}

Several more recent decisions have examined the argument in favor of legally recognizing a corporation's wider responsibilities apart from those resulting from actions creating corporate benefit. All have decided to uphold the particular action that has been attacked by shareholders. But in emphasizing improved employee attitudes or corporate public-spiritedness, the courts have subtly built a case for a finding of benefit. Questions of shareholders' ownership rights are rarely mentioned, though one senses that the use of the benefit test as at least partial support for a decision constitutes a judicial obeisance to the ownership concept.

In many respects, the first judicial recognition of corporate responsibility to a group other than shareholders is still the most liberal. In A.P. Smith Manufacturing Co. v. Barlow, ${ }^{49}$ the New Jersey Supreme Court upheld a donation to Princeton University by the defendant corporation. The court asserted that the donation could be justified solely as the company's recognition of its responsibility to the community. It indicated, however, that the corporation benefited from the gift in a very broad sense: its actions would aid its long run survival in a free enterprise system. ${ }^{50}$

The Delaware Chancery Court in Theodora Holding Corp. v. Henderson, ${ }^{51}$ a case involving a corporate contribution to a tax-exempt

44. Id. at 507,170 N.W. at 684 .

45. People ex rel. Metropolitan Life Ins. Co. v. Hotchkiss, 136 App. Div. 150, 120 N.Y.S. 649 (1909).

46. Armstrong Cork Co. v. H.A. Meldrum Co., 285 F. 58 (W.D.N.Y. 1922).

47. Better Business Bureau of Detroit, Inc. v. First Nat'l Bank, 296 Mich. 513, 296 N.W. 665 (1941).

48. Greene County Nat'l Farm Loan Ass'n v. Federal Land Bank, 57 F. Supp. 783 (W.D. Ky. 1944).

49. 13 N.J. 145, 98 A.2d 581 (1953).

50. Id. at 154,98 A.2d at 586 .

51. 257 A.2d 398 (Del. Ch. 1969). 
foundation, cited the New Jersey court with approval and warned that "[u]nless corporations carry an increasing share of the burden of supporting charitable and educational causes . . . the business advantages now reposed in corporations by law may well prove to be unacceptable to the representatives of an aroused public."s2

Few other courts have gone as far. Most have labored to find a corporate benefit to uphold a corporate charitable act. In Kelly v. $B e l l,{ }^{53}$ for example, the Delaware Chancery Court upheld the making by U.S. Steel of payments in lieu of taxes to a Pennsylvania county in which it did business on two grounds: responsibility to the community and corporate self-interest. The agreement to make such payments was conditioned on the passage of a law providing for a phasing out of the taxes (based on the value of machinery) that the payments replaced. The court indicated that the phasing out of the taxes would improve the depressed economic conditions in the county by encouraging industrial development, and that the addition of new industries to the county's tax base would ultimately ease U.S. Steel's tax burden. The corporation also benefited because, under the agreement, payments would not be made with respect to newly acquired machinery, although, under the old law, such machinery would have been added to the tax base. Though the plaintiff shareholders, suing derivatively, thought the payments a waste of corporate assets, the court disagreed. The payments, it said, "were made with a recognition of Steel's responsibility to the communities in which it was established and of its self-interest in having [the tax phase-out legislation] remain unaltered on the statute books." 44

In a similar manner, the Second Circuit applied New York law to test New York Telephone's contribution to a public-interest group that publicized views the company shared on a bond referendum relating to public transportation: “To the extent that NYT's contribution was prompted by a concern for the state of transportation and the multiplier effects on the economy as a whole it is protected [by statute]." 55 In addition, the court noted that, to the extent the contribution was prompted by an appreciation of the business benefits to be derived from better transportation, the corporate benefit rule also protected the contribution..$^{56}$

52. Id. at 404 .

53. 254 A.2d 62 (Del. Ch. 1969).

54. Id. at 74.

55. Schwartz v. Romnes, 495 F.2d 844, 854 (2d Cir. 1974) (dictum addressing a claim by plaintiffs of ultra vires).

56. Id. 
Occasionally a court's attempt to achieve the "correct" result and maintain the traditional attitude towards shareholders produces a rather curious hybrid. One example is the Tenth Circuit's decision in Herald Co. v. Seawell, ${ }^{57}$ which involved a shareholder's objections to a gift of shares to an employee stock option plan created by the Denver Post. The court acknowledged that it was "fully cognizant of the wellestablished corporate rule of law which places corporate officers and directors in the position of fiduciaries for the stockholders. Basic in that rule is the profit motive of the corporate entity." 58 Corporations that publish newspapers, however, are different; their duty, said the court, is more than profit making. Because their goal is to inform the public, they are a type of public institution with a duty to shareholders, employees and the public. ${ }^{59}$ Thus, if the corporation had to devote its attention to employees in an industry usually beset by labor troubles in order to ensure that the news reached the public, shareholders could not object. ${ }^{60}$

Even in these rather narrow lines of cases, recognition of management's right to consider groups other than shareholders when making decisions continues to be qualified. Without statutory change or some groundbreaking case precedent to guide them, courts can be expected to adhere, in differing degrees according to the philosophies of the judges, to old notions of shareholder supremacy.

It should be mentioned that a majority of state legislatures have passed corporation statutes expressly allowing corporate donations for charitable and other "public welfare" purposes. ${ }^{61}$ Several have progressed so far as to state that donations may be made "irrespective of business benefit."62 It is tempting to construe these provisions to cover corporate activities other than charitable contributions in their ordinary form. To do so, however, would strain actual legislative in-

57. 472 F.2d 1081 (10th Cir. 1972).

58. Id. at 1091 .

59. Id.

60. The appellate court's opinion subtly weaves both the public benefit and the newspaper's interest in the form of reduced labor strife to form the rationale supporting the case's result. Id. at 1095. In an interesting contrast to the Tenth Circuit's findings, the district court noted a less altruistic reason for the complained-of gift of shares to the stock plan trust fund: the major stockholders were attempting to ward off a take-over by a large newspaper chain. Herald Co. v. Bonfils, 315 F. Supp. 497 (D. Colo. 1970).

61. See, e.g., Cal. Corp. Code § 207(e) (West 1977); Del Code AnN. tit. 8, § 122(g) (1975); Mich. Stat. ANN. § 450.1261(k) (West 1973); TeX. Corp. \& Ass'Ns tit. 32, 1349 (Vernon 1962); ABA-ALI MODEL BUS. CORP. ACT $§ 4(\mathrm{~m})$ (1974).

62. See, eg., N.J. STAT. ANN. § 14A:3-4 (West 1969); N.Y. Bus. CoRp. LAw § 202(a)(12) (McKinney 1963). 
tent, which seems to have been simply to codify the law of modern cases. ${ }^{63}$ Also, it is questionable how courts view this type of statutory authorization since they continue to pay homage to the requirement of a corporate benefit. ${ }^{64}$

\section{The OWNership Model: The View from the Outside}

To many observers familiar with the operations of today's corporations, the courts' continuing emphasis on the conceptualization of shareholders as a corporation's owners is illustrative of the familiar judicial reluctance to relinquish old ideas. ${ }^{65}$ Even the sheer number of shareholders has weakened the proprietary underpinnings of the corporate ownership model. A decade ago Berle noted that twenty-four million Americans had invested in corporate shares, and a New York Stock Exchange study showed twenty-five million American shareholders in $1975 .{ }^{66}$ In addition, the only contact most individual shareholders have with the enterprise they supposedly own is their dividend check and a copy of the annual report. It is unlikely that a GM shareholder, while on a factory tour, would believe he would be taking one of "his" hubcaps if he picked up a replacement for his Pontiac. ${ }^{67}$

Changes in the patterns of share distribution have also weakened the shareholder-ownership model. The profile of the average American shareholder increasingly is not that of the white-collar worker investing in shares for his old age. Financial institutions, such as banks and pension funds, possess a large and growing percentage of the equity in American corporations. ${ }^{68}$ According to the New York Stock Exchange,

63. See, e.g., N.Y. Bus. CoRP. Law \& 202 (McKinney 1963); comment to id. § 202(a)(12).

64. See generally cases cited at notes $45-57$ supra.

65. More than one legal commentator has criticized the courts as well as legal reformers for the continued focus on the ownership model' as a drain on creative energy that could be better utilized to find analytical tools that explain real-world corporate relationships. For a particularly good analysis, see Hetherington, supra note 13.

66. Berle, Corporate Decision-Making and Social Control, 24 Bus. LAw. 149, 150 (1968); NEW YoRK Stock Exchange FACT BooK 50 (1977). The figures provided in the FACT BooK are taken from the most recent NYSE study of the investment market, conducted in 1975. However, the study revealed an actual decline in the number of shareholders, from a high of 30 million in 1970 to 25 million in 1975. Today, only one out of six Americans are shareholders, versus one out of four in 1970. This decline has been attributed to the period of economic recession in the early 1970 's that caused many smaller investors to leave the market.

67. See Kahn, Big Potato for a Day, THE NEw YoRker, June 17, 1950 at 65. For an interesting comparison of the same shareholder's attitude twenty years later, see Kahn, We Look Forward to Seeing You Next Year, THE NEw YORKER, June 20, 1970 at 40.

68. In 1964, Harbrecht estimated this percentage as approximately one-third of the outstanding shares of large industrial corporations. Harbrecht, The Modern Corporation Revisiled, 64 Colum. L. Rev. 1410, 1413 (1964). 
institutions hold approximately one-third of the Exchange's list of stocks. ${ }^{69}$ They currently rank among the largest shareholders in major American corporations. ${ }^{70}$ In terms of the traditional conceptualization of the shareholder's relationship to corporations, the actual "owners" of many corporations are therefore shareholders of shareholders. ${ }^{71}$

The emphasis on marketability of shares, with an easy way out provided by the stock market for the unhappy shareholder, and the demise of the shareholder vote as an effective tool of management control have also done much damage to traditional concepts implicit in the ownership model. ${ }^{72}$ The weakening of the ownership model corresponds to the rise in managerial power, which in turn raises such questions as: "For whom are the managers working?" and "Who is entitled to partake in the wealth generated by corporate activity?"73

Such questions are hardly new; they were first articulated nearly fifty years ago by A.A. Berle, Jr. and Gardiner Means in The Modern

69. New YoRK StOCK EXChANGe FACt BooK 53 (1977). This has held more or less constant from 1970 to 1975. A more significant indication, however, of the growing predominance of instututional shareholders is provided by a comparison of the relative numbers and the corresponding dollar volume of shares traded by institutional and individual shareholders. In the First quarter of 1976, an average of 44 million shares was traded daily on the NYSE. While the relative proportions of this total attributable to institutional and individual trading are fairly close (57\% vs. 43\%), the proportional dollar volume of shares traded by institutions was much greater than for individuals (excluding members trading on their own accounts): $70 \%$ to $30 \%$. Id. at 56.

70. In a recently-released U.S. Senate Governmental Affairs Subcommittee study, 21 large institutional investors were listed among the top identified voting rights shareholders of the 122 largest corporations, whose shares constitute $41 \%$ of the market value of all common shares outstanding. Wall St. J., Jan. 19, 1978, at 22, col. 2. See also New York Stock Exchange Fact Boox 50 (1977).

71. The prevalence of institutional shareholding means that more people in fact are relying on shareholding as a means of private wealth, albeit indirectly, through their participation or membership in financial institutions. But institutional shareholding also further removes the actual owners from any say in the use of productive property, and constitutes, in Berle's terminology, a second layer of passive property-holding. Berle, supra note 13, at 14. See also Harbrecht, supra note 68 , at 1414.

72. The efficient stock market machinery has in fact probably hastened the demise of the shareholder vote as an effective tool of control. Even though shareholders may be better informed about their corporations due to SEC vigilance, they are less interested in directly interfering with management and are much more likely to sell their shares than fight management. This attitude is especially prevalent among institutional investors. Hetherington, supra note 13, at 280-85; W. CARY, CORPORATIONS 238 (4th ed. 1969). Werner argues, however, that the market actually performs a control function for shareholders; the importance of market price and marketability allows shareholders to vote against management in the market by selling their shares. Werner, Management, Stock Market and Corporate Reform: Berle and Means Reconsidered, 77 CoLUM. L. REv. 388 (1977).

73. Questions concerning the proper beneficiaries of corporate wealth have increasingly occupied the attention of both courts and legal scholars. See, e.g., Theodora Holding Corp. v. Henderson, 257 A.2d 398 (Del. Ch. 1969); Chayes, The Modern Corporation and the Rule of Law, in THE CORPORATION IN MODERN SOCIETY 25 (E. Mason ed. 1960); Blumberg, supra note 38. 
Corporation and Private Property ${ }^{74}$ the seminal work on property ownership and corporations. This work's central thesis focused on the separation of ownership and control and on management's license to operate the corporation as a "purely neutral technocracy," without an enforceable responsibility towards shareholders, or any other group. ${ }^{75}$ "Separation of ownership from control" became the central concept of an entire literature examining the discrepancies between the "received legal model"176 of the corporation and its actual form. But this concern also provoked a well-known debate between Berle and Dodd ${ }^{77}$ on the issue of responsibility. For example, if power implies responsibility, to whom is management responsible? If not solely to shareholders, then to what other groups whose interests are affected by the corporation?

The Berle-Dodd dialogue centered essentially on the concept of trusteeship as the means to enforce responsibility among management, but with two contrasting applications. ${ }^{78}$ It was Dodd's belief that it was undesirable

to give increased emphasis . . . to the view that business corporations exist for the sole purpose of making profits for their stockholders ... . [P]ublic opinion, which ultimately makes law, has made and is today making substantial strides in the direction of a view of

74. See A. BERLE \& G. MEANS, supra note 15.

75. Id. 312. The emphasis on technical competence has not only led to the professionalization of management but, according to Galbraith, has created a substructure of technicians who form a technostructure within the corporation that sets corporate goals in terms of growth but also conditions corporate responses to external pressures. J. GALBRAITH, THE NEW INDUSTRIAL STATE (1972).

76. See M. EISENBERG, supra note 14 , at 139-48.

77. This debate stretched over nearly forty years, through a series of books, law review articles, book reviews and speeches treating the concept of managerial trusteeship and corporate responsibility. The principal works include: A. BERLE, THE 20TH CENTURY CaPITALIST RevolUTION (1954); Berle, Foreword to ThE CORPORATION IN MODERN SOCIETY ix (E. Mason ed. 1960); A. BERLE \& G. MEANS, supra note 15; Berle, supra note 66; Berle, Corporate Powers as Powers in Trust, 44 HaRv. L. REv. 1049 (1931); Berle, For Whom Corporate Managers are Trustees: A Note, 45 HARv. L. REv. 1365 (1932); Dodd, Is Effective Enforcement of the Fiduciary Duties of Corporate Managers Practicable?, 2 U. CHI. L. Rev. 194 (1935); Dodd, Trustees; Dodd, Book Review, 9 U. CHI. L. Rev. 538 (1942); Dodd, Book Review, 81 U. PA. L. Rev. 782 (1933). For an excellent analysis of this debate, see Weiner, The Berle-Dodd Dialogue on the Concept of the Corporation, 64 Colum. L. Rev. 1458 (1964).

78. Dodd warned in 1932 that there was a need for management to assume responsibility to repair the damage to society caused by the collapse of American business, and he chose the familiar concept of trusteeship to enforce this responsibility. Dodd, Trustees 1154-60. Berle on the other hand, while he agreed with Dodd's basic analysis of wider corporate responsibilities, harbored a profound suspicion of management's power and believed they could be trusted only with a responsibility to one group, namely shareholders. Berle, $A$ Note, supra note 77, at 1371-72. Interestingly enough, Dodd later modified his views concerning managerial trusteeship, bringing them closer to Berle's. Dodd, Book Review, 9 CHI. L. REv. 538, 546-47 (1942). See Weiner, supra note 77 , at $1462-63$. 
the business corporation as an economic institution which has a social service as well as a profit-making function . . . . ${ }^{79}$

According to Dodd, the institution of the corporation includes shareholders, employees, customers and the general public. As fiduciaries for the institution, managers in effect are trustees for those groups who have an interest in and are beneficiaries of that institution ("client-groups"). ${ }^{80}$ Berle sharply disagreed, insisting that the only clear-cut responsibility for management was to shareholders, a duty that the trusteeship concept already enforced. ${ }^{81}$

Despite their differences, Dodd and Berle both accepted shareholder ownership as the working principle from which to develop their theories on management's fiduciary duties. In fact, Dodd seemingly felt obliged to portray the corporation as a socio-economic institution in order to get around the legal obstacle raised by the "proprietary rights" of shareholder-owners. ${ }^{82}$

Bayless Manning, however, attacked even this basic assumption, taking a hard look at how shareholders behave. ${ }^{83} \mathrm{He}$ pointed out that modern shareholders rarely behave like corporate owners: few attend the annual meetings, important managerial proposals on mergers, option plans and the like are "virtually never rejected," and most shareholder votes have little significance until needed by one side or the other in a proxy fight. ${ }^{84}$ To Manning, the concept of ownership presents the greatest stumbling block in designing appropriate remedies for the real world. Manning's model would abandon this concept in favor of one that posits that the "only thing shareholders own is their stock":

To view the shareholder as the owner only of a share of stock-as a bondholder is said to own "the bond"-conforms far more closely to the shareholder's own expectations and describes far more accurately what he in fact handles as his own-buying, selling and giving away. ${ }^{85}$

One of the consequences of this approach is that management would have the widest discretion in business matters. ${ }^{86}$ It could legitimately

79. Dodd, Trustees 1148.

80. Dodd noted that business leaders have already adopted this attitude, citing in particular the comments of Owen D. Young, President of General Electric, concerning his trusteeship for those groups which have an interest in the corporation as an institution. Dodd, Trustees 1154, 1160.

81. Berle, $A$ Note, supra note 77 , at 1367-68.

82. Dodd, Trustees 1161-62.

83. Manning, Book Review, 67 YALE L.J. 1477 (1958).

84. Id. 1487.

85. Id. 1492.

86. Id. 1491. Manning's model of the shareholder contrasts sharply with existing case law. However, in a number of taxation cases courts have recognized the essentially risk-taking nature 
choose to attend to the wishes of a particular client-group after being conceptually freed from the limits imposed by shareholder-ownership. Managers would be relieved from the necessity of justifying their "corporate good citizenship" or "pro-customer" decisions to shareholders in order to protect themselves from legal objections.

The Berle, Dodd and Manning commentaries have provided a literature that comprises a fairly substantial portion of the body of scholarly legal writings on corporations. ${ }^{87}$ The topic of corporate responsibility has been frequently discussed throughout the activist years of the $60 \mathrm{~s}$ and into the 70s, especially with regard to the spectre of increased government regulation hovering menacingly over the corporation. ${ }^{88}$ Most proposals urging more corporate responsiveness to the enterprise's various client-groups blend Manning's observations with a variety of techniques to enforce management's responsibilities: a twotier board, emphasis on market mechanisms, or a type of "good business" rule that legitimizes the need for more responsiveness as the cost of doing business in today's society. ${ }^{89}$ No legislature or court has, however, even come close to adopting any of these proposals.

\section{Empirical Research Regarding Shareholders' EXPECTATIONS}

Neither in conceptualizing the relationship of shareholders to corporations, nor in determining whose interests managers should con-

of shareholding as a decisional principle to determine whether sums of money taken in income or deducted by a taxpayer were in the nature of loan interest or dividends. United States v. Title Guarantee \& Trust Co., 133 F.2d 990 (6th Cir. 1943); Helvering v. Richmond, 90 F.2d 971 (4th Cir. 1937); Fellinger v. United States, 238 F.Supp. 67 (N.D. Ohio 1964), affd, 363 F.2d 826 (6th Cir. 1966); Utility Trailer Mfg. Co. v. United States, 212 F. Supp. 773 (S.D. Cal. 1962).

87. In addition to those works cited throughout this Article, perhaps the most complete treatment of this subject may be found in THE CORPORATION IN MODERN SOCIETY (E. Mason ed. 1960). For examples of commentary from other disciplines, see Kaysen, The Social Significance of the Modern Corporation, 47 AMER. ECon. Rev. 311 (1957); P. DRUCKer, The NEw SocietY (1949).

88. Most commentators portray a dire cause-and-effect scenario of increased government intrusion into corporate affairs if corporations remain unmoved by pleas for more social responsiveness. See Blumberg, supra note 38, at 163-64; Friedmann, Corporate Power: Government by Private Groups and the Law, 57 ColuM. L. Rev. 155 (1957).

89. For one form of a two-tier corporate managerial structure, modeled along the lines of the German system, see Conard, Reflections on Public Interest Directors, 75 MrCH. L. Rev. 941, 94957 (1977). European proposals have included a French proposal calling for an annual company report on social activities by corporations and a British Conservative Party suggestion to allow company managers to take wider considerations into account in decision-making. CoMrTé D'ETUDe Pour La Réforme De L'ENTRePrise 204 (1975); Le bilan social dans les rapports des sociétees côtées en 1975, Bulletin Mensuel De la Commission Des Opérations De Bourse 7-8 (Dec. 1976); Dep't of Trade and Industry (U.K.), Company Law Reform 19-20 (1973). 
sider in decision making, have either courts or commentators focused on the expectations of shareholders. Courts have simply adopted centuries-old ideas about property ownership in coming to their formulations, and commentators have basically focused on the need of society for change. Yet shareholders' expectations are important to consider, for if those who are to benefit from the traditional conceptualizations and decision-making rules do not expect the benefits, either the conceptualizations and rules should change or a new basis for them should be found.

With this in mind, the authors concluded that shareholders should be asked questions which would determine two things: first, what their perception was of the shareholders' relationship to the corporation, and second, whose interests they felt should be considered in corporate decision making. The authors accomplished this by means of a questionnaire completed by 466 shareholders of large, publicly held corporations. ${ }^{90}$ For comparison purposes, we also administered the questionnaire to 116 first-year Notre Dame Law School students who did not own stock in this type of corporation. ${ }^{91}$

\section{A. Shareholders' Relationship to Corporations.}

As shown in Table 1, we approached the question of the shareholder's relationship to his corporation by asking for agreement or disagreement with various statements. Some statements were designed to address the issue obliquely and some quite directly. The responses of shareholders and law students were roughly congruent, except for the responses to statements 1 and 2 (relating to the similarity of owning stock in a corporation and lending money to one). For statements other than these two, a majority of shareholders and law students expressed agreement to at least some degree.

90. The questionnaire was sent to 1,000 persons, living predominantly east of the Rocky Mountains, whose names appeared on a commercial mailing list of shareholders in public corporations. By our cut-off date for data-processing, we had received 495 processable replies, and 53 questionnaires which were undeliverable (yielding a return rate of $52 \%$ ). Of the 495 persons responding, 466 teported they were currently shareholders in one or more large, publicly-held corporations. The shareholder sample was overwhelmingly male $(96.8 \%$ males, $1.3 \%$ females and $1.9 \%$ not answering the question). Their mean age and education were 56.8 years and 16.88 years, respectively.

91. This sample constituted virtually the entire first-year class, excepting 34 students who indicated they currently owned stock in one or more large, publicly-held corporations. The nonshareholder sample was $69 \%$ male and $31 \%$ female. Their mean age was 23.23 years and they averaged 16.10 years of education. The questionnaires were completed during a law school class held during the first weeks of the school year. 


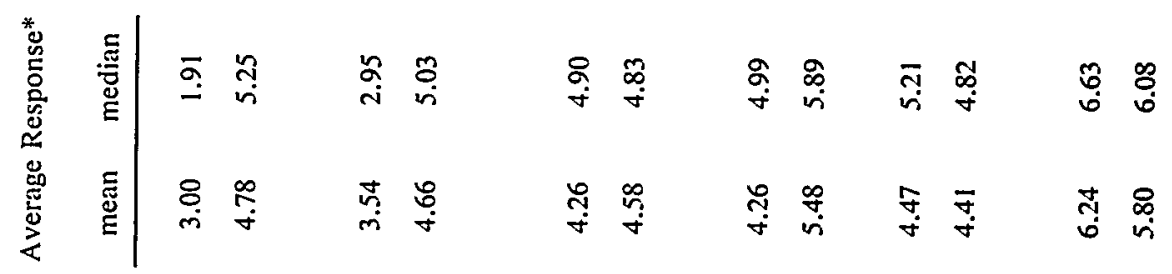

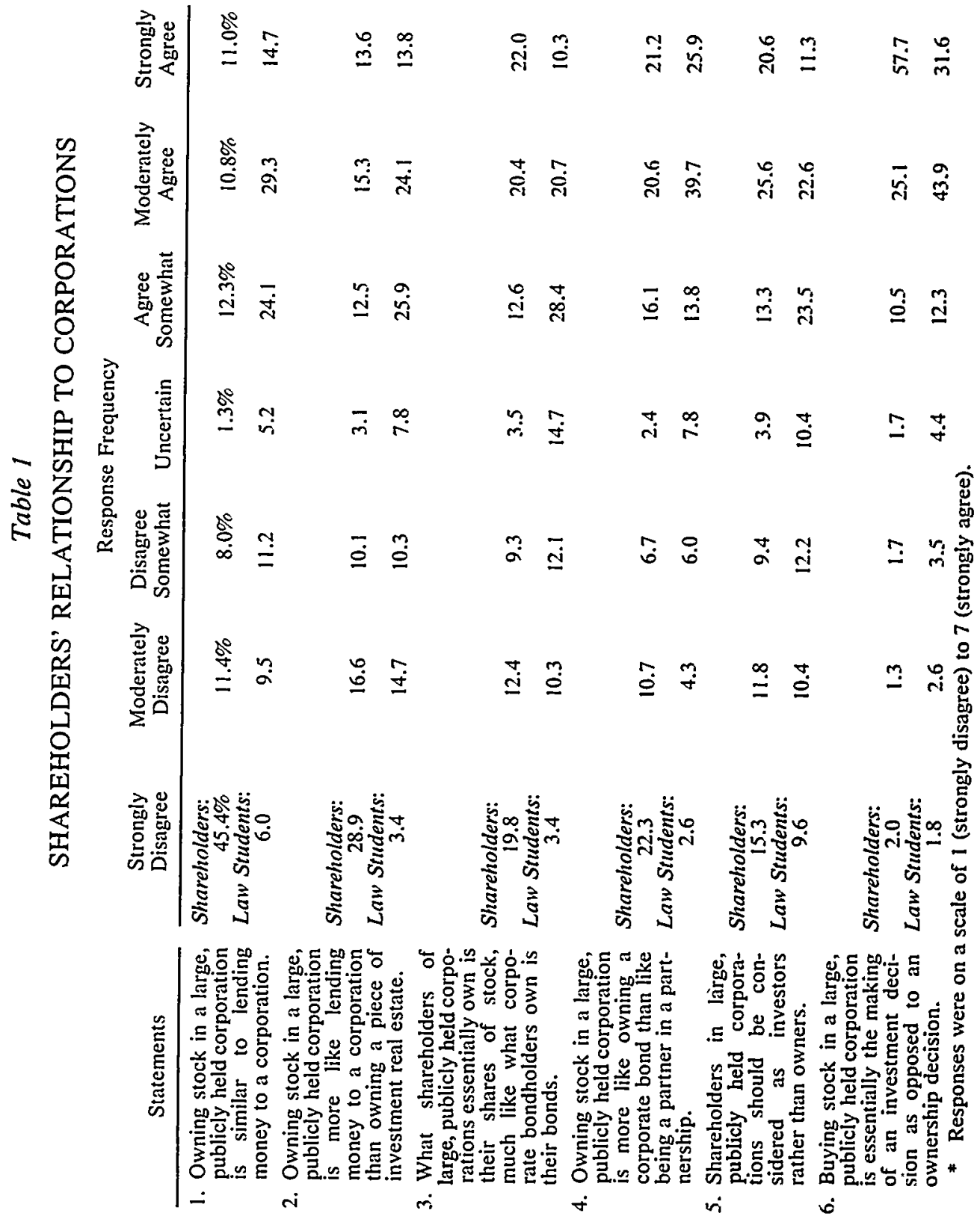


For our purposes, statements 3,5 and 6 are the most important. The responses clearly indicated acceptance of the proposition that shareholders should be considered investors rather than owners. Of the shareholders, $59.5 \%$ agreed with a direct wording of that proposition in statement 5. Obviously, the concepts of "investor" and "owner" are not mutually exclusive, but it should be noted that statement 5 was phrased as if they were for the purpose of decision making. The responses to statement 6 (that buying stock is essentially an investment decision as opposed to an ownership decision) perhaps provides some basis for understanding the responses to statement 5 . A total of $93.3 \%$ of the shareholders agreed with statement 6 , with $57.7 \%$ strongly agreeing. More importantly, statement 3 refines the investor-owner dichotomy by putting it in rather bald terms (that what shareholders essentially own are their shares, much as what bondholders own are their bonds). Fifty-five percent of the shareholders agreed with that proposition.

\section{B. Corporate Responsibility to Client-Groups.}

We approached the issue of corporate responsibility to clientgroups in two ways. First, we asked respondents to rank-order specified client-groups according to the responsibility a large, publicly held corporation owes them. Respondents also indicated whether they believed such a corporation actually owes no responsibility to one or more groups (other than because of laws such as tax laws, zoning laws, health and safety laws, and so on). Second, as in the case of the question regarding the shareholder's relationship to his corporation, we asked for agreement or disagreement with certain statements relating to groups that might be considered in corporate decision making.

Table 2 displays the results of the ranking portion of the survey. There was a marked general agreement between shareholders and law students in the order of ranking. ${ }^{92}$ For both groups of respondents, the same three client-groups (shareholders, customers and employees) were ranked in the top three, though in different order. With respect to the other four client-groups, both shareholders and law students ranked government last and local community above suppliers.

There were, however, interesting differences between the shareholders' and the law students' responses. Compared to the range of the median rankings of the shareholders (1.28-6.76), the range of rankings by the law students (2.66-6.53) was less extreme. Comparing the values in the column headed "Percentage ranking this client-group first" reveals what is partially responsible for this difference: shareholders ex-

92. The correlation between shareholders' and law students' rankings was equal to .79 , which is statistically significant at the .05 level. 
Table 2

CORPORATE RESPONSIBILITY TO CLIENT-GROUPS: GROUP RANKING

\begin{tabular}{|c|c|c|c|c|c|}
\hline & \multicolumn{2}{|c|}{ Rank } & \multirow{2}{*}{$\begin{array}{c}\text { Percentage } \\
\text { ranking this } \\
\text { client-group } \\
\text { first }\end{array}$} & \multirow{2}{*}{$\begin{array}{l}\text { Percentage } \\
\text { ranking this } \\
\text { client-group } \\
\text { in top three }\end{array}$} & \multirow{2}{*}{$\begin{array}{l}\text { Percentage indi- } \\
\text { cating no re- } \\
\text { sponsibility to } \\
\text { this client-group }\end{array}$} \\
\hline & mean & median & & & \\
\hline \multicolumn{6}{|l|}{ Shareholders } \\
\hline Shareholders & 1.62 & 1.28 & $64.2 \%$ & $94.7 \%$ & $0.0 \%$ \\
\hline Customers & 2.26 & 2.25 & 28.8 & 91.5 & 0.0 \\
\hline Employees & 2.51 & 2.40 & 3.5 & 93.1 & 0.0 \\
\hline Local community & 4.56 & 4.54 & 0.0 & 7.9 & 1.3 \\
\hline Suppliers & 5.22 & 5.25 & 0.2 & 3.5 & 5.3 \\
\hline Society in general & 5.28 & 5.55 & 3.5 & 9.0 & 5.5 \\
\hline Government & 6.53 & 6.76 & 0.0 & 0.7 & 19.1 \\
\hline \multicolumn{6}{|l|}{ Law Students } \\
\hline Customers & 2.82 & 2.66 & $19.0 \%$ & $73.3 \%$ & $0.0 \%$ \\
\hline Employees & 2.90 & 2.71 & 12.1 & 66.4 & 0.0 \\
\hline Shareholders & 3.22 & 2.89 & 26.7 & 59.4 & 0.0 \\
\hline Society in general & 3.46 & 3.23 & 34.5 & 53.4 & 0.9 \\
\hline Local community & 3.78 & 3.87 & 6.9 & 37.1 & 0.0 \\
\hline Suppliers & 5.71 & 5.94 & 0.0 & 6.1 & 1.7 \\
\hline Government & 6.12 & 6.53 & 0.9 & 4.3 & 6.9 \\
\hline
\end{tabular}

Note: Ranking was on a scale of 1 (most responsibility owed by large, publicly-held corporations) to 7 (least responsibility owed by such corporations). Also, respondents could indicate they believe a large, publicly-held corporation owes no responsibility to one or more of the groups (other than because of tax laws, zoning laws, health and safety laws and so on).

pressed a clear first place choice in the rankings (64.2\% placed shareholders first) whereas law students did not (their first place choice received only $19 \%$ of the first place indications and their fourth place choice received the greatest percentage of first place indications). This result is of course not surprising, since present shareholders who have an investment at stake would want to be considered first by the corporation in its decision making. Finally, with the shareholders, there was a clear "breaking point" after the first three groups with respect to all indicators, suggesting a greatly diminishing concern for the interests of client-groups below that point. Notice, for example, the relatively large drop in average rankings between employees and local community ( 2.51 to 4.56 for the means and 2.40 to 4.54 for the medians). Notice also, in the column headed "Percentage ranking this client-group in top three," the precipitous drop between the percentages for employees (93.1\%) and local community (7.9\%). The law students' responses also displayed a fairly clear breaking point, but it occurred lower in the rankings: between local community (ranked fifth) and suppliers (ranked sixth). 
Perhaps most enlightening were the responses of shareholders and law students when given the opportunity to indicate that corporations owe no responsibility to one or more of these groups (other than because of certain types of laws). No shareholder or law student chose to indicate "no corporate responsibility" toward shareholders, customers or employees. With respect to the other groups, government, at $19.1 \%$, received the greatest percentage of either shareholders or law students indicating no responsibility. As in the case of other indicators of breaking points between groups, responses to this portion of the survey revealed a breaking point for the shareholders after the first three groups and for the law students after the fifth group.

The validity of the present study is somewhat borne out by a study published in 1977 by Brenner and Molander..$^{93}$ They surveyed readers of the Harvard Business Review, mostly business managers, ${ }^{94}$ with respect to various corporate responsibility issues. In their study they included a client-group ranking section virtually identical to ours. On the same one to seven scale, their results were as follows: ${ }^{95}$

\begin{tabular}{lr} 
client-group & mean rank \\
\hline customers & 1.83 \\
shareholders & 2.52 \\
employees & 2.86 \\
local community & 4.44 \\
society in general & 4.97 \\
suppliers & 5.10 \\
government & 5.72
\end{tabular}

These rankings displayed a general congruence with those of shareholders and law students: the same client-groups were ranked in the top three by each group of respondents, government was ranked last and local community was ranked before suppliers. Again, there was a clear breaking point between client-groups (at the same point as in the shareholder survey), suggesting that after the third-ranked group there was a greatly reduced concern for client-group interests.

93. Brenner \& Molander, Is the ethics of business changing?, HARv. Bus. REv. 57 (Jan.-Feb. 1977).

94. Of 5,000 readers polled, 1,227 responded (a return rate of $25 \%$ ). Seventy-six percent of these respondents were managers in some form of organization (including some non-corporations). The non-manager respondents were primarily employed in business in staff positions or were professional persons. The survey respondents were $94 \%$ male. Thirty percent had college degrees and $60 \%$ had attended graduate school. An average age was not reported, but $37 \%$ were between 30 and 40 years old, $26 \%$ were between 40 and 50 and $19 \%$ were between 50 and 60 . Id. at 58.

95. Id. 
The results of the second part of the corporate responsibility portion of our survey are shown in Table 3. In this portion of the survey, the shareholders and law students displayed the greatest agreement. Not only are the levels of general agreement relatively close $(88.5 \%$ and 94.0\% for statement 1 and $97.0 \%$ and $91.3 \%$ for statement 2 ), but the percentages of shareholders and law students at each level of agreement are similar. Some differing responses by shareholders and law students to the two statements, however, raise interesting questions. Why, for example, are the average responses to the two statements virtually identical for law students and quite different for shareholders? ${ }^{96}$ We surmise that shareholders had greater sophistication and discerned differences in the statements that law students missed. Why, also, did the shareholders exhibit a higher level of strong agreement with the second statement than with the first $(75.1 \%$ for the second statement as opposed to $41.3 \%$ for the first). ${ }^{97}$ Several possible explanations are: (1) the first statement was specific-it related to moving a plant-and therefore gave shareholders details to disagree with; (2) the problems caused by the moving of a plant are not uncommon, and many shareholders may have developed conflicts on an issue with which they fundamentally agree; and (3) suppliers and people in the local community were named as client-groups in the second statement, and these groups ranked low in the shareholders' group rankings. But, whatever the reasons for these differences, the most important result of this portion of the survey is unambiguous: shareholders strongly agree that in making corporate decisions, the interests of client-groups other than shareholders should be considered.

\section{Conclusion: New GUidelines for MANAGement}

In light of the results of the above research, the authors believe that the traditional conceptualization of the shareholder's relationship to the corporation is faulty insofar as it gives shareholders, because they are "owners," special consideration in management decision making affecting other client-groups. In actuality, shareholders expect to be treated as "investors," much like bondholders for example, and expect corporate managers to consider a wide constituency when making corporate decisions. ${ }^{98}$ Their expectations should be met.

96. The difference for the shareholders was statistically significant beyond the .001 level $(Z=-9.52)$, while for the law students the difference was, of course, not significant $(Z=0.0)$.

97. A $Z$-test on the significance of the difference between proportions revealed that the difference was significant beyond the .001 level $(Z=10.18)$.

98. It should be noted that we are referring to non-institutional shareholders and to what they expect generally-not to what they might hope would be the case in situations where their own money is at stake. It is the expectations of noninstitutional shareholders that are important to consider, since in the final analysis real people are behind all institutional investors, either as shareholders or as some other beneficiary. Also, the expectations of shareholders in situations of personal involvement are not nearly as relevant for this discussion as are their general expectations. When their own money is involved, shareholders may feel quite differently. 


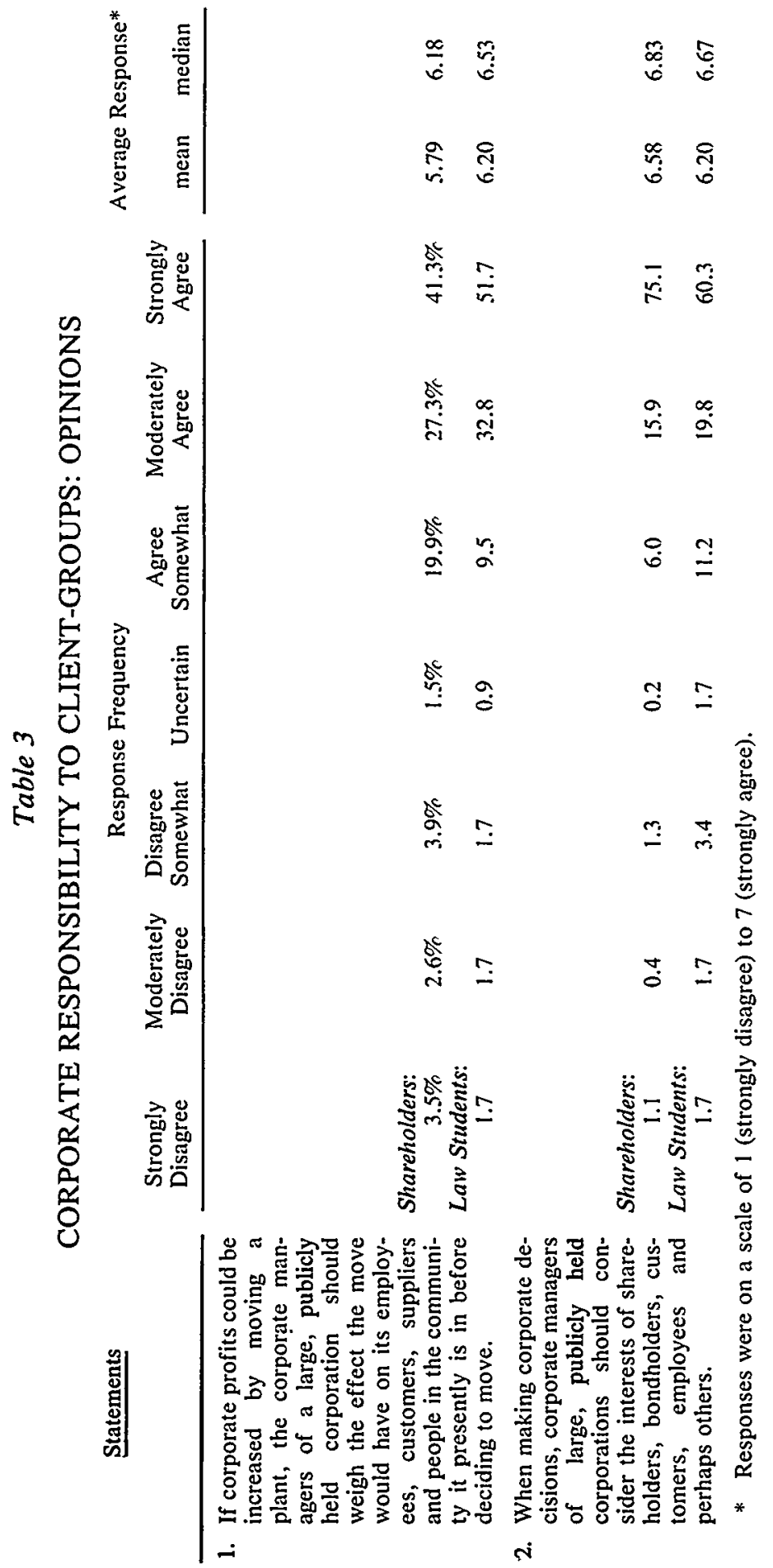


Toward meeting these expectations, corporate managers should be required - either by statute or case law-to consider all of the corporation's client-groups when making decisions. The list of client-groups used in the questionnaire is of course not complete, nor was it intended to be. The authors suggest that it be left to each corporation's managers to determine the relevant client-groups of their corporation. This task would not be overly difficult if fairly broad categories (such as those used in the questionnaire's list) are employed. It should also be left to each corporation's managers to balance the interests of each clientgroup. Clearly no one could legislate a group ranking, or interestweighing formulation, that would be generally usable, and studies such as the one discussed in this Article can only be used to gain insights, and not answers, to the question of which groups should be considered in a particular situation.

The general congruence between shareholders', law students' and managers' rankings in our and Brenner and Molander's surveys does provide some helpful insight into which groups might reasonably be expected to rank high or low on corporate managers' lists. It seems clear, for example, that shareholders, customers and employees could be expected to rank high and government low (perhaps because the concept of "government" is not very meaningful in this context). Also, one could expect no major changes in corporate decision making with respect to employees because of the existence of the collective bargaining process.

With respect to shareholders, it must be remembered that what mainly interests them is the market price of their shares. This is affected in the long run primarily, though by no means exclusively, through profits. And in the long run (which managers should be free to consider more important in decision making than the short run), reasonable profits are absolutely necessary to the interests of all client-groups. Shareholders would therefore not be slighted in corporate decisionmaking since any required balancing of interests must ultimately allow for reasonable profits. The authors will leave to others the discussion of what profits are "reasonable." For purposes of this Article, the authors recognize that to be reasonable to shareholders, profits must be acceptable to the investment community. The profits must be viewed in the stock market as "good," "solid," "increasing" and so on. It should be remembered in this connection that concepts such as these are relative. Assuming managers of all corporations are forced to abide by the same corporate responsibility rules, then the fact that one corporation's profits may be less than they otherwise might be because of the balancing of client-group interests would be of little consequence-other corporations' profits would probably also be less. 
Even if the concept of reasonable profits is left aside for the moment, the question arises as to how much profit should be "spent" on balancing client-group interests. Considering the importance of profits to each client-group, very little should be spent. This can perhaps best be discussed in connection with balancing the interests of customers and shareholders. Let us assume management is faced with the following situation: rising costs force either a decrease in product quality or an increase in price, if profits are to reach a certain desired level. As is not unlikely, we will assume this level is one several cents a share above last year's profit level (so as to keep profits growing). We will also assume that management has decided that the comparative prices of competing products are such that the cost cannot be passed on to customers. If the per share decrease in profit would be relatively minor and would still allow growing profits, it would be reasonable for the corporate managers to be able to say, "Our customers deserve our present quality product, and they are going to get it." If, however, the profit short-fall would eliminate or substantially decrease the hoped-for rise in profits, it would be most reasonable for management to take the steps necessary to protect the profits.

The willingness to grant rights to client-groups implies the willingness to give the means to enforce these rights. The authors propose, therefore, that client-groups be allowed to bring class-action or derivative suits against corporations for the failure by corporate management to balance their interests. At first this may seem likely to lead to a multitude of lawsuits, each involving large expenditures of corporate money and management time and each ultimately being decided by a judge or jury substituting its own brand of balancing for that of the corporate managers. Such is not the case. The business judgment rule, in its present form, should serve as an almost absolute bar to the winning of (and in most cases to the bringing of) this kind of suit, except in the most egregious cases (i.e., those involving the absence of a good faith attempt either to identify client-groups to be considered in decision-making, or to balance their interests). ${ }^{99}$ If any weakness in that rule becomes apparent in this context, that rule should be strengthened so as effectively to bar suit in all but the most egregious cases. ${ }^{100}$

Will management willingly accept the proposed new rules? Any management prepared to act in good faith would have no reason to fear lawsuits. But more importantly, we wonder if the new rules would in most cases do anything more than allow corporate managers to be hon-

99. For a good short statement of the rule, and a voluminous collection of authority, see $\mathrm{H}$. HENN, supra note 4, at 482.

100. See Manning, supra note 83 , at 1491 . 
est with themselves and the world regarding the reasons for their decisions. While there is no shortage of rhetoric by corporate managers regarding corporate responsibility, these managers usually seem to feel the need to explain that socially responsible behavior is in the corporation's interest (presumably, that socially responsible behavior will yield profits, at least in the long run). ${ }^{101}$ Although this is often true, it is not always so; sometimes decisions made in favor of client-group interests cost something in terms of profitability. The Brennner and Molander study, if accurate, suggests that managers are presently considering client-groups other than shareholders in their decision making. The authors believe it desirable for managers to be free to say so; candor about corporate decisions is in everyone's interests, including those of shareholders. Managers might therefore welcome these proposed changes-though they may not feel able to admit it publicly.

The question also arises as to how radical a change is being proposed. James J. Kilpatrick, a man few would describe as radical, has said recently:

Somewhere in this broad land a few corporate relics of the 19th Century may still be operating in the pattern of the public be damned; a few molding tycoons may still be wedded to concepts of the sweat shop, child labor, foul pollution, and to grinding the faces of the poor.

The far more typical corporation has an entire department of public relations. It has advertising agencies, personnel specialists, recreation consultants, community advisers, cafeteria managers, the whole nine yards. The typical corporation has a budget for philanthropy, for fine art, for gardens, for guided tours, for tea and crumpets. ${ }^{162}$

While we wonder if Kilpatrick missed the mark by including advertising agencies and public relations departments in his list, he raised the

101. General Motors' Chairman, Thomas A. Murphy, has said, for example:

General Motors recognizes the obligation that it has to respond to the changing requirements of our society and the increased expectations which society has for the business community. We also realize that we do business in a world of finite resources and that the long-run viability of our Company depends, in the final analysis, on our ability to adapt to rapidly changing conditions.

1976 General Motors Public Interest Report, inside cover.

Walter A. Haas, Chairman of Levi Strauss \& Co., echoes this theme:

We believe that a corporation must become actively involved in facing and solving the social problems of America. Today's corporation must develop practical means of giving human needs the same status as profit and production . . . . In the long run, this new task of the corporation will be in its own best interest; since it cannot prosper as fully or as long in a society frustrated by social ills and upheaval.

Statement of J. Kreps Before the State, Justice, Commerce and Judiciary Subcommittee of the House Committee on Appropriations 3 (Jan. 23, 1978).

102. Washington Star, Feb. 4, 1978, at A-11, col. 4-8. 
important issue of corporate philanthropy. A.P. Smith and the cases that have followed it, ${ }^{103}$ along with the widely adopted statutory provisions allowing charitable contributions by corporations, ${ }^{104}$ have clearly paved the way for the changes suggested by this Article. It would be no revolutionary act for courts or legislatures to do away with whatever vestiges may remain of the corporate benefit rule as it relates to charitable contributions ${ }^{105}$ and to extend the basic doctrine of A.P. Smith to bring client-groups, other than shareholders, within the area of legitimate management concern.

103. See text accompanying notes 49-56 supra.

104. See statutes cited at notes 61-62 supra and accompanying text.

105. See text accompanying notes 50-64 supra. 
